E-ISSN: 2502-6674

P-ISSN: 2502-6666

http://ojs.uho.ac.id/index.php/p_sejarah_uho

\title{
ANAK PUTUS SEKOLAH STUDI KASUS DI DESA LAMBELU KECAMATAN PASIKOLAGA KABUPATEN MUNA ${ }^{1}$

\author{
CHILDREN DECIDE SCHOOL STUDY CASE IN VILLAGE LAMBELU SUBDISTRCT \\ PASIKOLAGA MUNA DISTRICT ${ }^{I}$ \\ Murtia $^{2}$ \\ e-mail: murstia223@gmail.com
}

Pendais Hak ${ }^{3}$

e-mail:pendaishak@uho.ac.id

\author{
${ }^{1)}$ Hasil Penelitian Tahun 2019, ${ }^{2)}$ Alumni jurusan Pendidikan Sejarah, ${ }^{3)}$ Dosen FKIP UHO
}

\begin{abstract}
ABSTRAK: Permasalahan yang dikaji dalam Penelitian ini adalah; 1) apakah penyebab anak putus sekolah di Desa Lambelu Kecamatan Pasikolaga Kabupaten? 2) bagaimana upaya mengatasi anak putus sekolah di Desa Lambelu Kecamatan Pasikolaga Kabupaten Muna? Metode yang digunakan dalam penelitian ini adalah pendekatan deskriptif kualitatif dengan tahapan-tahapan sebagai berikut; 1) Observasi 2) wawancara 3) Dokumentasi (Sugiyono, 2016; 224). Tinjauan pustaka dalam penelitian ini yaitu menggunakan konsep teori perubahan sosial, konsep pendidikan, konsep pendidikan formal, konsep putus sekolah, dan faktor-faktor penyebab anak putus sekolah. Hasil penelitian ini menunjukkan bahwa; 1 . penyebab anak putus sekolah yang terjadi di Desa Lambelu yaitu faktor internal dan faktor eksternal. a. Faktor internal yang berasal dari diri anak yaitu; kurangnya minat anak untuk sekolah dan rendahnya motivasi anak merupakan penyebab anak putus sekolah di Desa Lambelu Kecamatan Pasikolaga Kabupaten Muna. b. Faktor eksternal yang berasal dari luar diri anak yaitu; Kondisi ekonomi orang tua, lingkungan pergaulan yang kurang baik, dan Perkawinan Usia Muda. 2. upaya mengatasi anak putus sekolah di Desa Lambelu Kecamatan Pasikolaga Kabupaten Muna dalam penelitian ini adalah : 1) Adanya upaya orang tua dalam memberikan motivasi bagi anaknya untuk melanjutkan pendidikan, 2) Adanya upaya dari sekolah untuk memperhatikan pendidikan siswa dan bahkan diayomi atau mendekatkan diri dan memberikan arahan serta dukungan akan arti pentingnya pendidikan dan upaya pemerintah yaitu dengan memberikan bantuan PIP dan BOS serta bekerja sama dengan pemerintah desa untuk memberikan pemahaman kepada masyarakat, orang tua siswa tentang pentingnya pendidikan.
\end{abstract}

Kata Kunci : Upaya, Penyebab, Metode, Anak putus sekolah

ABSTRACT: The problems examined in this study are; 1) what is the cause of children dropping out of school in Lambelu Village, Pasikolaga District, Regency? 2) how to deal with school dropouts in Lambelu Village, Pasikolaga District, Muna Regency? The method used in this research is a qualitative descriptive approach with the following stages; 1) Observation 2) interview 3) Documentation (Sugiyono, 2016; 224). Literature review in this study is to use the concept of social change theory, the concept of education, the concept of formal education, the concept of dropping out of school, and the factors causing dropouts. The results of this study indicate that; 1. causes of school dropouts that occur in Lambelu Village are internal and external factors. a. Internal factors originating from the child, namely; lack of children's interest in schooling and low motivation of children are the causes of school dropouts in Lambelu Village, Pasikolaga District, Muna Regency. b. External factors originating from outside the child, namely; The economic condition of parents, unfavorable social environment, and Early Marriage. 2. efforts to overcome dropout children in Lambelu Village, Pasikolaga District, Muna Regency in this study are: 1) There is an effort by parents to provide motivation for their children to continue their education, 2) There is an effort from schools to pay attention to the education of students and even protect them or get closer and provide direction and support for the importance of education and government efforts, namely by providing PIP and BOS assistance and working with village governments to provide understanding to the community, students' parents about the importance of education.

Keywords: Efforts, Causes, Methods, Children dropping out of school 


\section{PENDAHULUAN}

Pendidikan merupakan hal yang penting dari kehidupan manusia. Dengan pendidikan, manusia bisa menempati kedudukan yang lebih tinggi. Manusia yang berpendidikan digolongkan menjadi manusia yang lebih dihormati dan disegani oleh manusia yang lain. Dengan kata lain, pendidikan merupakan sarana untuk meningkatkan harkat dan martabat manusia. Selain itu, perkembangan suatu bangsa dapat ditentukan pula oleh maju mundurnya bidang pendidikan di suatu bangsa tersebut. Oleh karena itu pelaksanaan pendidikan harus dilakukan dengan penuh tanggung jawab dan sebaik-baiknya agar seorang individu mampu meningkatkan pengetahuan dan keterampilan. Sehingga bermanfaat bagi kepentingan hidupnya sebagai pribadi dan anggota masyarakat serta mampu menyesuaikan diri dengan lingkungan yang selalu berubah.

Dalam Undang-Undang No. 20 Tahun 2003 tentang Sistem Pendidikan Nasional, disebutkan bahwa tujuan pendidikan nasional adalah untuk berkembangnya potensi peserta didik agar menjadi manusia yang beriman dan bertaqwa kepada Tuhan Yang Maha Esa, berakhlak mulia, sehat, berilmu, cakap, kreatif, mandiri dan menjadi warga negara yang demokratis serta bertanggung jawab. Ini menunjukkan bahwa pendidikan sangat penting untuk menciptakan manusia-manusia terdidik yang mampu mendorong Indonesia agar lebih maju lagi. Pentingnya akan pendidikan diperkuat lagi dalam pasal 31 ayat 1 UUD 1945 yang berbunyi "setiap warga negara berhak mendapat pendidikan".

Selain itu Mashun $(2010 ; 11)$ pendidikan adalah usaha sadar dan terencana untuk mewujudkan suasana belajar dan proses pembelajaran agar peserta didik secara aktif mengembangkan potensi dirinya untuk memiliki kemampuan spritual keagamaan, penegendalian diri, kepribadian kecerdasan ahlak mulia serta keterampilan yang diperlukan dirinya, masyarakat, bangsa dan negara.

Usaha pemerintah dalam pemerataan akses pendidikan diupayakan melalui program wajib belajar sembilan tahun. Hal ini di tegaskan dalam Undang-Undang Dasar dimana "setiap warga negara memiliki hak yang sama dalam memperoleh pendidikan yang bermutu" sehingga peran masyarakat dibutuhkan dalam perencanaan, pelaksanaan pengawasan dan evaluasi program pendidikan. selain itu orang tua juga memiliki kewajiban untuk menyekolahkan anaknya untuk memasuki usia sekolah, sehingga hak anak untuk memperoleh informasi dan pengetahuan dapat terpenuhi.

Menurut Idris (Asni, 2012;13) mengatakan pendidikan formal lembaga yang membantu lingkungan keluarga yang bertugas mendidik dan mendidik serta memperbaiki tingkah laku anak didik. Pendidikan formal yang menunjukan bentuk yang nyata, dalam arti komponen komponennya tersusun secara formal. Komponen-komponen itu misalnya bahan pendidikan, metode, media tujuan, organisasi dan sebagainya. Lingkungan pendidikan formal adalah sekolah sebagai pendidikan formal, maka sekolah timbul sebagai akibat perkembangan masyarakat dan budaya yang kompleks, yang diciptakan untuk membantu lingkungan pendidikan yang sudah ada, yakni keluarga

Namun pelaksanaan pendidikan tidak selamanya berjalan dengan baik karena munculnya persoalan persoalan yang kompleks. Persoalan pendidikan yang sering muncul yaitu kaitannya dengan kondisi orang tua. Kondisi orang tua berperan sebagai penentu keberlangsungan pendidikan anak, antara lain kondisi sosial dan kondisi ekonomi. Selain itu, kondisi anak itu sendiri juga berpengaruh terhadap minat anak untuk tetap melanjutkan pendidikan. Hal tersebut sama yang dialami oleh masayarakat desa Lambelu yang dimana masih ada anak yang mengalami putus sekolah atau berhenti sekolah.

Menurut Gunawan (2004: 71) putus sekolah merupakan predikat yang diberikan kepada mantan peserta didik yang tidak mampu menyelesaikan suatu jenjang pendidikan, sehingga tidak dapat menyelesaikan melanjutkan pendidikan ke jenjang pendidikan berikutnya. Selanjutnya Imron (2004: 125) menyatakan yang dimaksud anak putus sekolah 
adalah anak yang dinyatakan telah keluar dari sekolah yang bersangkutan sebelum waktu yang telah ditentukan atau sebelum dinyatakan lulus dan mendapat ijazah dari sekolah.

Menurut Buharudin Salam (2002: 14) mengemukakan bahwa keluarga merupakan lembaga pendidikan yang pertama dan utama, berlangsung secara wajar, dan informal serta melalui media permainan. Keadaan keluarga berlainan satu sama lain. Ada keluarga yang kaya, ada yang kurang mampu, ada keluarga yang besar (banyak anggota keluarga), ada pula keluarga yang kecil. Ada keluarga yang bercekcok dan gaduh dan sebagainya. Dalam keluarga yang bermacam-macam seperti inilah yang membawa pengaruh terhadap pendidikan dan minat sekolah anak (Purwanto, 84 : 2007).

Desa Lambelu adalah Desa yang jauh dari kota Raha. Meski di desa ini ada sekolah SD, MTsN, dan Aliyah untuk anak-anak yang ada di desa tersebut agar tidak sekolah di luar. Namun tetap saja diantara anak masih mengalami putus sekolah, permasalahannya adalah ekonomi yang dimiliki oleh orang tua, lingkungan pergaulan, dan faktor perkawinan usia muda. Berdasarkan uraian di atas maka penulis tertarik untuk mengadakan penelitian dengan judul anak putus sekolah tingkat pendidikan Aliyah di desa Lambelu Kecamatan Pasikolaga Kabupaten Muna.

\section{METODE PENELITIAN}

Penelitian ini telah dilaksanakan pada bulan januari sampai bulan Februari tahun 2019. Tempat penelitian ini dilaksanakan di Desa Lambelu Kecamatan Pasikolaga Kabupaten Muna. Dengan menggunakan pendekatan deskriptif kualitatif dimana peneliti berusaha untuk mengkaji dan mendeskripsikan data-data yang diperoleh dilapangan tentang anak putus sekolah di Desa Lambelu Kecamatan Pasikolaga Kabupaten Muna. Dan upaya mengatasi anak putus sekolah.

Jenis dan sumber data dalam penelitian ini adalah dengan cara pengambilan data primer dan sekunder; (1) data primer, yaitu data yang paling utama dijadikan sebagai bahan analisis yang akan diteliti, dimana data yang diperoleh tersebut langsung dari informan yang menjadi subjek penelitian. dimana data ini diperoleh secara langsung dari lapangan melalui wawancara 5 anak putus sekolah, 6 orang tua anak putus sekolah dan 4 tambahan merupakan guru Madrasah Aliyah, Kepala sekolah dan Kepala Desa Lambelu dan kepala sekolah SD 1 Pasikolaga yang menjadi informan dalam penelitian ini. (2) data sekunder, yaitu sebagai data pendukung atau pelengkap yang berupa catatan-catatan dari dokumen yang terdapat di Kantor Desa Lambelu Kecamatan Pasikolaga Kabupaten Muna.

Teknik penentuan subjek dari penelitian ini yaitu dengan menggunakan teknik purposive sampling adalah teknik pengambilan sampel sumber data dengan pertimbangan tertentu. (Sugiyono 2016;301). Pertimbangan yang dimaksud dalam pengambilan subjek adalah keterwakilan untuk bisa memberikan informasi yang aktual yaitu kompetensi pemahaman dari seseorang terhadap fokus penelitian.

Teknik pengumpulan data merupakan langkah yang paling strategis dalam sebuah penelitian, Sebab tujuan utama dari penelitian adalah mendapatkan data yang akurat, sehingga tanpa mengetahui teknik pengumpulan data peneliti tidak akan mendapatkan data yang memenuhi standar yang ditetapkan [sugiyono, 2016; 224]. Teknik pengumpulan data yang digunakan dalam penelitian ini adalah dengan menggunakan metode observasi, wawancara, dan dokumentasi.

Analisis data dalam penelitian kualitatif dilakukan terus menerus sepanjang proses penelitian berlangsung, yang dilakukan secara deskriptif kualitatif dan interpretatif. Analisis data dilakukan mulai dari perumusan masalah, pengumpulan data dan pasca pengumpulan data. Dengan adanya perumusan masalah maka peneliti telah melakukan 
analisis terhadap permasalahan tersebut dalam berbagai prespektif teori dan metode yang digunakan. Berdasarkan hal tersebut maka peneliti akan melakukan proses pengumpulan dan analisis data sepanjang rangkaian kegiatan penelitian dituangkan dalam penulisan hasil penelitian. Jadi, analisis data dalam penelitian ini adalah melakukan penyederhanaan data yang terkumpul, yang selanjutnya diolah, ditafsirkan, dan melakukan pemaknaan terhadap data yang telah terkumpul tersebut, kemudian disajikan secara sistematis. Komponen utama dalam proses penelitian menurut spradley, yakni; (1) analisis domain, (2) analisis taksonomi, (3) analisis kompenesial, dan analisis tema kultural. (Sugiyono, 2017: 129). Namun, dalam penelitian ini peneliti hanya mengambil tiga yakni analisis domain, analisis taksonomi, analisis komponen.

Pemeriksaan keabsahaan data merupakan salah satu bagian sangat penting di dalam penelitian kualitatif yaitu untuk mengetahui derajat kepercayaan hasil penelitian yang telah dilakukan. Apabila peneliti melaksanakan pemeriksaan terhadap keabsahan data secara dengan mengunakan teknik sangat tepat, peka akan diperoleh hasi penelitian yang benarbenar dipertanggurng jawabkan dari berbagai segi yaitu sebagai berikut;

1. Ketekunan Pengamatan; Meningkatkan ketekunan berarti melakukan pengamatan secara lebih cermat dan berkesinambungan. Dengan cara tersebut maka kepastian data dan urutan peristiwa akan di rekam secara pasti dan sistematis (Sugiyono, 2017: 167).

2. Triangulasi; Triangulasi dalam pengujian kreadibilitas ini di artikan sebagai pengecekan data dari berbagai sumber dengan berbagai cara, dan berbagai waktu. Adapun dalam triangulasi ini terdapat beberapa bagian yaitu; Triangulasi Sumber; Triangulasi Teknik; Triangulasi Waktu

\section{HASIL PENELITIAN DAN PEMBAHASAN}

\section{A. Penyebab Anak Putus Sekolah di Desa Lambelu Kecamatan Pasikolaga Kabupaten Muna}

Kasus anak putus sekolah tentunya tidak akan terlepas dari beberapa hal yang mempengaruhi anak sekolah sehingga tidak dapat menyelesaikan sekolah, wajar saja terjadi karena anak dihadapkan oleh beberapa kendala, baik yang datang dari diri sendiri maupun yang datang dari luar diri anak yaitu lingkungan. Di Desa Lambelu, anak yang putus sekolah pada dasarnya memiliki jenjang pendidikan di sekolah yang berbeda-beda, untuk jenjang Sekolah Dasar, anak-anak bersekolah di SDN 1 Pasikolaga, MTsN 5 Muna dan jenjang Sekolah Madrasah Aliyah Al-Muhajirin Lambelu. Berikut ini penjelasan anakanak yang putus sekolah berdasarkan asal sekolah sesuai dengan hasil penelitian dalam tabel sebagai berikut : 
Tabel: 1

Anak Putus Sekolah di Desa Lambelu Berdasarkan Asal Sekolah

\begin{tabular}{lcc}
\hline \multicolumn{1}{c}{$\begin{array}{c}\text { Tingkat } \\
\text { Pendidikan }\end{array}$} & Jumlah & Jumlah Anak putus sekolah \\
\hline SD 1 Pasikolaga & 185 & 3 Orang siswa SDN 3 Lambelu \\
MTsN 5 Muna & 100 & - \\
M. Aliyah Al- & 57 & 10 orang siswa Madrasah Aliyah \\
Muhajirin Lambelu & & Al-Muhajirin Lambelu \\
\hline
\end{tabular}

Sumber Data : Hasil Olahan Data anak putus sekolah 2018

Berdasarkan data pada tabel di atas, jumlah anak putus sekolah Desa Lambelu tingkat pendidikan SD dan Madrasah Aliyah berjumlah 13 orang anak. Sedangkan asal sekolah dari SDN 1 Pasikolaga berjumlah 3 orang, dan Madrasah Aliyah Al-Muhajirin Lambelu berjumlah 10 orang. Hasil penelitian menunjukan bahwa, di Desa Lambelu terdapat 13 orang anak yang putus sekolah dan tidak dapat melanjutkan pendidikan ke jenjang yang lebih tinggi di mana di sebabkan oleh beberapa faktor baik itu faktor internal dan eksternal.

Anak putus sekolah yang di maksud dalam penelitian ini adalah tidak selesainya masa pendidikan anak selama bersekolah baik itu pada jenjang tingkat SD dan Madrasah Aliyah yang ada di Desa Lambelu. Untuk mengetahui jumlah anak putus sekolah berdasarkan hasil penelitian yang ada di Desa Lambelu pada tahun 2018, dapat di lihat pada tabel sebagai berikut:

Tabel 2

Data Anak Putus Sekolah di Desa Lambelu Tahun 2018

\begin{tabular}{|c|c|c|c|}
\hline Tingkat & \multicolumn{2}{|c|}{ Jenis Kelamin } & \multirow[t]{2}{*}{ Jumlah } \\
\hline & Laki-Laki & Perempuan & \\
\hline SDN 1 Pasikolaga & 3 & - & 3 \\
\hline MTsN 5 Muna & - & - & - \\
\hline M. Aliyah Al- & 5 & 5 & 10 \\
\hline Muhajirin Lambelu & & & \\
\hline Total & 8 & 5 & 13 \\
\hline
\end{tabular}

Sumber Data : Hasil Olahan Data anak putus sekolah Tahun 2018

Tabel di atas, jumlah anak putus sekolah di Desa Lambelu pada tahun 2018 berjumlah 13 orang, yang terdiri dari 8 orang laki laki dan 5 orang perempuan. Dari tingkat SD terdiri dari 3 orang laki-laki, dari tingkat Madrasah Aliyah terdiri dari 5 orang perempuan dan 5 orang laki-laki. Dalam penelitian ini sebagai mana hasil penelitian di lapangan sudah di lakukan faktor penyebab anak-anak putus sekolah di Desa Lambelu di pengaruhi oleh beberapa faktor penyebab yaitu faktor internal dan ekstenal antara lain sebagai berikut:

1. Faktor Internal.

Faktor internal merupakan faktor penyebab anak putus sekolah yang berasal dari diri anak. Adapun penyebab anak putus sekolah di Desa Lambelu yaitu:

a. kurangnya minat anak untuk bersekolah Pendidikan tanggung jawab keluarga terutama orang tua, akan tetapi juga tanggung jawab harus di sertai dengan kemaun dari anak itu sendiri untuk sekolah. Antara pendidikan dan kemauan anak merupakan suatu sisi yang saling membutuhkan dan saling mempengaruhi. Apabila kemauan anak kuat tetapi 
dukungan orang tua tidak ada sama saja membuat anak tidak mau sekolah lagi, ini akibat banyaknya anak putus sekolah. Oleh karena itu antara kemauan anak dan dukungan orangtua harus sejalan. Anak putus sekolah mengatakan bahwa penyebab anak putus sekolah dikarenakan tidak ada minat anak untuk bersekolah. Orang tua selalu memberikan perhatian dan dukungan untuk bersekolah dan kebutuhan sekolah selalu terpenuhi akan tetapi kemauan dari diri anak untuk bersekolah tidak ada lagi karena merasa bosan dan jenuh selama belajar disekolah. sehingga menyebabkan anak berhenti sekolah. (Hasim, wawancara 12 februari 2019).

Pandangan lainnya penyebab anak putus sekolah mengatakan bahwa anak putus sekolah dikarenakan minat atau kemauan untuk bersekolah itu kurang karna malas untuk berangkat kesekolah padahal apa yang menjadi kebutuhanya di sekolah terpenuhi saya juga sudah sering menasehati bahkan memarahi agar kesekolah tetapi dari anak tersebut tidak mau mendengarkannya. karena disekolah gurunya kadang masuk kadang tidak. Inilah yang menjadikan anak putus sekolah. (WD. Azmiati 17 januari 2019)

Selanjutnya hasil wawancara dari salah satu informan orang tua anak putus sekolah mengatakan bahwa anak putus sekolah dikarenkan karena malas untuk pergi kesekolah, kesekolah saja mesti harus di bujuk-bujuk karna kurangnya minat untuk sekolah membuat dia bermalas-malasan untuk kesekolah padahal orang tuanya berharap dia terus bersekolah, akan tetapi anak tersebut sudah tidak mau sekolah lagi. (Tini 17 januari 2019). Rendahnya minat atau kemauan anak untuk bersekolah Salah satu faktor penyebab anak putus sekolah di Desa Lambelu Kecamatan Pasikolaga Kabupaten Muna di karnakan rendahnya minat yang ada dari dalam diri untuk bersekolah. Rasa malas dan kemauan untuk belajar di sekolah membuat anak memutuskan untuk berhenti sekolah.

b. Rendahnya Motivasi

Tingkat motivasi seorang anak sangat berpengaruh terhadap keingin anak untuk terus bersekolah, motivasi ini bisa berasal dari keluarga, lingkungan dan anak itu sendiri. Kemauan anak untuk berhenti sekolah juga di sebabkan karena sudah jenuh dalam mengikuti pelajaran dan apa lagi guru-guru yang membosankan membuat anak-anak malas untuk mengikuti proses belajar mengajar dengan efektif.

Penyebab anak putus sekolah yaitu karena malas mengikuti proses belajar mengajar ia lebih memilih tidak masuk belajar ketimbang belajar, karena menurutnya belajar itu membosankan. (wawancara 17 januari 2019). Pandangan lainnya mengatakan bahwa anak putus sekolah dikarenakan kurangnya motivasi anak untuk sekolah, menurutnya bejar itu membosankan setiap hari pergi sekolah dan belajar begitu begitu terus, Sehingga hal ini akan menjadikan anak putus sekolah. (wawancara 17 januari 2019)

2. Faktor Eksternal

Faktor eksternal merupakan faktor penyebab anak putus sekolah yang berasal dari luar diri anak. faktor eksternal terdiri dari; faktor ekonomi, pergaulan, dan perwinan usia muda.

a. Faktor Ekonomi

Manusia adalah makhluk bebas yang memiliki hak dan kewajiban. Melanjutkan pendidikan atau berhenti adalah pilihan. Walaupun perekonomian orang tua bisa membiayai biaya sekolah, namun jika keinginan untuk melanjutkan sekolah tidak ada, maka anak tersebut akan mengalami putus sekolah. Seseorang yang keluar dari sekolah atau putus sekolah ada yang didasari keinginan sendiri. Memilih putus sekolah tentunya ada alasan. Secara garis besar anak memilih putus sekolah karena tidak ingin menyusahkan orang tua. 
Faktor Penyebab anak putus sekolah dikarenakan keterbatasan ekonomi dan ketidakmampuan untuk membiayai sekolah. Kebutuhan sehari hari saja susah apalagi tidak ada pekerjaan yang menetap, Kalau berbicara Ada keinginan untuk bersekolah ada keinginan untuk sekolah akan tetapi lagi lagi keadaan ekonomi yang tidak mampu membiayai kebutuhan sekolah khususnya pembayaran komite dan akhirnya memutuskan merantau untuk membantu ekonomi orang tua. (Wa Hasa, wawancara 12 Februari 2019)

Sejalan dengan hal tersebut putus sekolah akibat ekonomi keluarga. berhenti sekolah karena tidak memiliki biaya sebab sejak kecil tinggal dengan nenek, melihat dengan keadaan yang serba pas-pasan apalagi di tambah dengan kebutuhan sekolah. dari pada menyusahkan orang tua, akhirnya memilih untuk berhenti sekolah dan ikut bekerja membantu orang tua. (wawancara 20 januari 2019)

Anak putus sekolah dikarenakan kondisi ekonomi orang tua yang dimana orang anak putus sekolah tidak mampun membiayai pembayaran sekolah perbulanya. Maka anak-anak tersebut mereka lebih fokus dan berfikir untuk membantu orang tua mencari nafka tanpa berpikir lagi untuk bersekolah sehingga pendidikan dipikiran merekadikesampingkan, uanglah yang mereka utamakan. (wawancara 28 januari 2019). Sedangkan menurut kepala sekolah SDN 1 Pasikolaga mengatakan bahwa Kemampuan ekonomi orang tua hanya cukup memahami kebutuhan hidup sehari-hari, kesadaran orang tua tentang pentingnya pendidikan yaitu orang tua tidak pernah bertanya tentang keinginan anak bersekolah (wawancara 13 mei 2019)

Kondisi ekonomi orang tua yang menyebabkan anak putus sekolah meliputi tingkat pendapatan dan beban tanggungan keluarga. Tingkat pendapatan berkaitan juga dengan pekerjaan. Yang dimana Orang tua anak putus sekolah adalah seorang petani dan wiraswasta sehingga pendapatan mereka juga tidak dapat dipastikan. Kondisi ekonomi merupakan faktor yang berasal dari latar belakang keluarga anak putus sekolah yaitu kesadaran orang tua akan pendidikan, faktor ekonomi akan berdampak pada anak sehingga anak harus membantu orangtua mencari nafkah. Dimana faktor ini merupakan pendukung utama untuk mendukung pendidikan anak, karena dengan ekonomi yang memadai biaya pendidikan anak akan dapat terpenuhi. Sebaliknya, apabila keadaan ekonomi orang tua kurang mampu, maka kebutuhan anak dalam bidang pendidikan tidak akan dapat terpenuhi. Sebagian orang tua anak beranggapan bahwa pendidikan merupankan beban yang paling berat dan mahal tidak mampu mereka menjangaunya, jadi inilah yang membuat anak mereka putus sekolah.

\section{b. Faktor Lingkungan Pergaulan}

lingkungan pergaulan yang kurang baik merupakan salah satu faktor yang menyebabkan terjadinya anak putus sekolah dikalangan remaja. Hal ini yang sedang menjadi fenomena dikalangan anak usia sekolah, banyak anak yang putus sekolah dikarenakan pergaulan yang kurang baik dengan sesama teman. Begitupun yang terjadi di Desa Lambelu Kecamatan Pasikolaga Kabupaten Muna, terdapat anak yang putus sekolah karena pengaruh lingkungan pergaulan dengan sesamanya, karena salah memilih teman sehingga terdapat anak yang terpengaruh untuk mengikuti kebiasaan temannya padahal kebiasaan tersebut berdampak buruk terhadap sekolahnya.

Hasil wawancara yang diperoleh dari salah satu informan orang tua anak putus sekolah mengatakan bahwa penyebab anak putus sekolah dikarenakan pengaruh lingkungan pergaulan dimana pada saat jam belajar mereka tidak mengikuti pelajaran yang 
berlangsung pada saat itu, mereka memilih nogrong dan merokok bersama teman teman di luar lingkungan sekolah ketimbang mengikuti proses belajar mengajar. (wa Erni wawancara 17 februari 2019)

Hasil wawancara yang lain juga mengatakan bahwa penyebab anak putus sekolah dikarenakan teman pergaulan. teman pergaulan yang dimana dapat mempengaruhi belajar siswa, teman yang kurang baik dapat membawa akibat anak itu juga tidak baik yang pada akhirnya menyebabkan anak putus sekolah. Pengaruh-pengaruh dari teman bergaul anak lebih cepat masuk dalam jiwanya. Teman bergaul baik akan akan berpengaruh baik begitu pula sebaliknya teman yang kurang baik pasti berpengaruh buruk pula. (Ratna wawancara 17 februari 2019)

Menurut hasil wawancara dengan kepala sekolah SDN 1 Pasikolaga mengatakan anak yang putus sekolah di SD 1 Pasikolaga dikarenakan Lingkungkungan pergaulan tempat tinggal anak tersebut, dimana sebagian kecil ditempat tinggal anak tersebut yang tidak bersekolah sehingga anak terpengaruh inilah yang menyebabkan anak berhenti sekolah. (wawancara 13 mei 2019)

Pada dasarnya keluarga merupakan lingkungan sosial yang paling kecil, tetapi merupakan lingkungan paling dekat dan kuat dalam mendidik anak, terutama bagi anak yang belum memasuki bangku sekolah. Dengan demikian seluk beluk kehidupan keluarga mempunyai pengaruh yang paling mendasar dalam perkembangan anak. Keluarga mempunyai peranan yang penting dalam perkembangan anak, sedangkan keluarga yang jelek akan berpengaruh negatif. Oleh karena itu, anak sejak kecil dibesarkan oleh keluarga. c. Perkawinan Usia Muda

perkawinan merupakan suatu ikatan yang menunjukkan hubungan antara dua insan yang saling mencintai satu sama lain. Sebuah ikatan perkawinan terjadi karena adanya kecocokkan pribadi, psikologi, rasiodan fisik. Oleh sebab itu hubungan pernikahan ini merupakan penyatuan antara pribadi dan antara individu yang jelas berbeda tabiatnya.

Pernikahan dini merupakan sebuah perkawinan dibawah umur yang target persiapannya belum dikatakan maksimal dengan meliputi persiapan fisik, mental, juga persiapan materi. Ketiga persiapan inilah yang seharusnya dijadikan sebagai persyaratan jika seseorang sudah siap untuk mengakhiri masa remajanya dan sudah siap untuk masuk dalam masa tua atau akan mempunyai keluarga sendiri. Banyak orang tua yang ingin menikahkan anaknya di usia muda mereka tanpa mempertimbangkan umur atau usia itu semua dilakukan karena keterbatasan pengetahuan orang tua terhadap makna perkawinan itu sendiri.

Namun hal di atas berbeda dengan anak-anak yang berada di Desa Lambelu Kecamatan Pasikolaga Kabupaten Muna, Mereka menikah dari kemauan sendiri dan kawin lari. Kawin lari yang dimaksud disini yaitu ketika terjadi sesuatu yang tidak diinginkan oleh masyarakat terlebih orang tua mereka sendiri. Dan hal inilah yang menjadi penyebab mereka putus sekolah.

Hal di atas sebagaimana dialami oleh salah satu informan yang bernama Sartina yang berusia 17 tahun, putus sekolah kelas 2 Aliyah, mengatakan bahwa putus sekolah dikarenakan menikah muda atas kemauan dari diri sendiri. Alasanya karena pengen hidup bersama-sama calon suami walaupun orang tua tidak setuju tetap mereka pengen menikah, dan akhirnya mereka memutuskan untuk kawin lari. Mendengar hal itu orang tua anak putus sekolah tidak setuju akan tetapi dengan keadaan yang sudah terlanjur akhirnya orang tua hanya pasrah dan menyetujui untuk menikah. (Sartina, wawancara 22 januari 2019) 
Hal tersebut senada dengan yang diungkapkan oleh salah satu informan yang merupakan orang tua anak putus sekolah mengatakan bahwa anak putus sekolah dikarenakan sudah tidak mau sekolah lagi, biar dikasih arahan tentang pentingnya sekolah buat masa depan tetap dari dirinya sendiri sudah tidak mau, seiring berjalannya waktu tibatiba dari salah satu pihak keluarga mengatakan bahwa badria ini sudah berada dirumah imam. Mendengar hal itu sekeluarga tidak setuju akan tetapi mau diapa sudah terlanjur kejadiannya seperti itu akhirnya kedua bela pihak menikahkan mereka. (Sanima, wawancara 17 januari 2019)

Selain yang melakukan pernikahan dini, ada pula yang melakukan pernikahan dini karena adanya faktor hamil di luar nikah. Seperti yang diungkapkan oleh salah satu informan yang merupakan orang tua anak putus sekolah mengatakan bahwa anak putus sekolah dikarenakan melakukan perbuatan yang tidak baik, perbuatannya tersebut membuat sekeluarga malu, tapi mau diapa sudah terlanjur meskipun kami menegurnya dengan keras sudah tidak ada gunanya, jadi kami hanya menunggu untuk menikahkannya, untuk bertemu saja dengan teman-temannya tidak berani karena merasa malu. (Tini, wawancara 17 januari 2019)

Harapan orang tua terhadap anak yaitu ingin menjadikan anaknya berguna baik bagi dirinya sendiri maupun orang lain. Namun, masa remaja merupakan masa-masa dimana tingginya rasa keingin tahuan jika dikontrol atau dicegah dari pihak orang tua hal tersebutlah yang akan terjadi karena terlalu bebas dan sudah tidak bisa ditangani akibatnya seorang anak menjadi korban dan pendidikan bukan hal terpenting bagi mereka.

Lingkungan pergaulan buat anak adalah sesuatu yang harus di masuki karena lingkungan pergaulan seseorang, anak bisa terpengaruh ciri kepribadiannya, tentunya di harapkan terpengaruh hal-hal yang baik, di samping bahwa lingkungan pergaulan adalah sesuatu kebutuhan dalam pengembangan diri untuk hidup bermasyarakat, karena itu lingkungan sosial sewajarnya menjadi perhatian kita semua agar bisa menjadi lingkugan yang baik yang bisa meredam dorongan-dorongan negatif pada anak. Masalah kehamilan diluar nikah pada anak disebabkan karena kurangnya kontrol sosial orang tua terhadap media massa yang begitu canggih adalah penyebab terjadinya kenakalan anak terutama mengenai kehamilan diluar nikah, pudarnya nilai moral dan norma agama di masyarakat yang menyebabkan kurangnya kontrol sosial terhadap para pelaku kejahatan termasuk kenakalan anak berupa kehamilan diluar nikah, dan sikap permisif orang tua, masyarakat beserta tokoh masyarakat terhadap pendidikan dan pengembangan diri pada anak mengenai sosialisasi reproduksi pada anak baik dampak pernikahan dini serta dampak kehamilan di usia muda.

\section{Upaya Mengatasi Anak Putus Sekolah di Desa Lambelu Kecamatan Pasikolaga Kabupaten Muna}

Dalam dunia Pendidikan bukan hanya menjadi tanggung jawab sekolah saja, tetapi juga menjadi tanggung jawab semua masyarakat terkhusus orang tua. Konsekuensinya, semua warga Negara memiliki kewajiban moral untuk menyelamatkan pendidikan. Sehingga ketika ada anggota masyarakat yang tidak bersekolah hanya karena tidak punyah uang, maka masyarakat yang kayam atau tergolong sejahtera memilik kewajiban moral untuk menjadi orang tua asuh bagi kelangsungan pendidikan anak yang putus sekolah.

Pemerintah sangat mempunyai peranan yang sangat penting dan tanggung jawab yang besar dalam menangani masalah keterputusan anak-anak usia sekolah baik laki-laki maupun perempuan karena pemerintah akan merasa bangga dengan kesuksesan yang 
dicapai oleh generasi penerus bangsa dan negara namun kini tidak bisa kita pungkiri ternyata sekarang ini sudah banyak generasi-generasi penerus bangsa kita yang mengalami putus sekolah.

Adapun upaya-upaya yang harus di lakukan untuk mengatasi penyebab anak putus sekolah di Desa Lambelu dalam penelitian ini adalah : 1) Adanya peran orang tua dalam memberikan motivasi bagi anaknya untuk melanjutkan pendidikan, 2) Adanya peran dari sekolah untuk memperhatikan pendidikan siswa dan bahkan di ayomi atau mendekatkan diri dan memberikan arahan serta dukungan akan arti pentingnya pendidikan.

\section{Upaya Orang Tua}

Upaya yang dilakukan untuk mengatasi anak putus sekolah di Desa Lambelu adalah diperlukan tindakan orang tua terhadap anak yang mengalami putus agar anak melanjutkan sekolah kembali. Dengan tindakan tindakan yang dilakukan oleh orang tua agar anak meraka bisa melanjutkan sekolah, seperti pemberian motivasi kepada mereka meraka, memberikan apapun yang mereka inginkan sebagai syarat mereka masuk ke sekolah juga sudah mereka upayakan. Orang tua harus memperhatikan dan sadar akan pentingnya pendidikan anak mereka, hal tersebut dengan memberikan dan dukungan dan motivasi baik moral maupun material.

Orang tua yang harus lebih memperhatikan siswa tersebut dengan memberikan perhatian lebih lagi terutama dalam hal pendidikan dengan cara selalu memberikan motivasi belajar setiap harinya agar siswa juga bisa bersemangat untuk bersekolah dan mengenyam pendidikan. Masyarakat sekitar harus lebih jeli dengan pergaulan anak-anak di desa misalnya dengan memberikan atau mengajar nilai keagama dan sosial serta memberikan motivasi arahan tentang pentingnya pendidikan dan sekolah.

Hal tersebut sebagaimana yang di ungkapkan oleh Harmawati S.Pd selaku guru Aliyah, mengatakankan bahwa orang tua harus memberikan perhatian, motivasi dan kepedulian mereka akan pentingnya pendidikan bagi anak-anaknya, memberikan waktu untuk saling bertukar pendapat agar terjalin kedekatan dengan anak, sehingga anak merasa dipedulikan oleh orang tua yang akan membuat mereka bersemangat untuk bersekolah. (wawancara 28 2019)

Hasil wawancara lainnya dari salah satu informan yang merupakan orang tua anak putus sekolah mengatakan memberikan motivasi belajar setiap harinya agar anak biar bersemangat untuk bersekolah, rasa peduli, perhatian dan dukungan baik moral maupun material serta mengontol pergaulan anak saya, rasa dengan terpenuhinya itu biasa mencegah anak-anak untuk putus bersekolah. (wa Erni wawancara 17 januari 2019)

Hasil wawancara lainnya dari salah satu informan yang merupakan orang tua anak putus sekolah mengatakan bahwa harus berusaha dan tekad kuat meski terkendala ekonomi saya akan meminta bantuan sekolah mendiskusikan bagaimana upaya agar anak kelak tetap bersekolah dengan memberi motivasi agar tetap terus belajar, mengupayakan agar saya bisa memenuhi kebutuhanya selama bersekolah karna dengan sekolah anak biasa mendapatkan banyak ilmu yang dapat kelak nantinya di pergunakan dan dimanfaat untuk kelangsungan hidup. (Wa hasa wawancara 17 januari 2019)

Peran orang itu sangat penting dengan memberikan motivasi-motivasi, rasa peduli, menyemangati, mensuport, memberi perhatian serta memenuhi apa yang menjadi kebutuhnya di sekolah dan mengontol pergaulan anak demi masa depan yang dimana dengan pendidikan yang akan menjadi penunjang masa depannya serta mengajar nilai keagama dan sosial serta memberikan motivasi arahan tentang pentingnya pendidikan dan 
sekolah maka anak bisa membuat anak tidak berhenti bersekolah dan terus bersekolah agar dapat meraih cita-cita mereka.

\section{Upaya Sekolah}

Untuk sekolah Madrasah Aliyah yang ada di Desa Lambelu upaya untuk mengatasi yang dikukan oleh pihak sekolah dari putus sekolah dilakukan dengan tindakan yang telah diambil oleh sekolah terhadap siswa yang bersangkutan ini adalah bentuk kepedulian dan perhatian sekolah terhadap siswanya yang tidak berkeinginan melanjutkan sekolah. Pihak sekolah dengan kolaborasi orangtua dalam hal ini telah diupayakan agar siswa-siswa yang putus sekolah bisa kembali mengenyam pendidikan. Mengingat lingkungan sekolah ini adalah lingkungan dimana siswa bisa mendapatkan pendidikan formal selain pendidikan di lingkungan rumahnya. Dan dengan mengadakan kerja sama antara orang tua dengan guruguru.

Mengatasi anak putus sekolah yaitu anak yang tidak berminat sekolah seorang pendidik harus beradaptasi dan berkomunikasi dengan orang tua siswa agar oranng tua dapat memantau kondisi ananknya, Karena katika orang tua lengah maka anak juga ikut lengah. Jadi harus ada komunikasi dan kerja sama antara anak didik, orang tua dengan guru sehingga anak itu betul-betul terkontrol jadi anak tersebut ada keraguan untuk tidak berhenti sekolah. Melakukan pendekatan terhadap orang tua dan memberikan pemahaman tentang pentingnya pendidikan dan melakukan koodinasi dengan pihak sekolah agar siswa yang kurang mampu diberikan perhatian khusus. Pihak sekolah akan membuat suasana persekolah menjadi nyaman bagi mereka membuat siswa itu tidak bosan dan jenuh agar mereka beta selama berada disekolah dan pulang sesuai jam pelajaran berakhir serta menjalin kedekatan dengan siswa-siswi agar mereka tidak merasa terabaikan dan diperhatikan selama di sekolah dan mengajak siapa siapa anak berhenti sekolah di desa lambelu untuk bersekolah kembali.

Upaya pihak sekolah dalam mengatasi anak putus sekolah, pertama yaitu mengusulkan bantuan program indonesia pintar (PIP) itu bagi anak yang kurang mampu melalui pendataan data dapodik yang kedua memberi biaya transportasi dan keperluan alat-alat sekolah melalui dana BOS, ketiga bekerja sama dengan pemerintah setempat dalam hal ini pemerintah desa untuk memberikan pemahaman kepada masyarakat dalam hal ini orang tua siswa tentang pentingnya pendidikan, keempat mengusulkan kepada pemerintah desa untuk diberi bantuan melalui dana desa itu memberikan siswa dari biaya pendidikan.

Untuk mengatasi faktor penyebab anak putus sekolah di Desa Lambelu baik itu karna dari dirinya sendiri dan diluar dirinya sendiri dengan mengadakan melakukan pendekatan terhadap orang tua dan memberikan pemahaman tentang pentingnya pendidikan dan melakukan koodinasi dengan pihak sekolah agar siswa yang kurang mampu diberikan perhatian khusus dan juga membuat suasana persekolah menjadi nyaman bagi mereka membuat murid itu tidak bosan dan jenuh agar mereka beta selama berada disekolah, serta dengan menjalin kedekatan dengan orang tua siswa apa bila ada orang tua siswa yang terkendala dengan ekonomi yang tidak mampu memenuhi kebutuhan sekolah pihak sekolah akan mengundang orang siswa untuk mencari solusi agar anak tetap melanjutkan pendidikan serta orang tua mengontol pergaulan anak demi masa depan yang dimana dengan pendidikan yang akan menjadi penunjang masa depannya serta mengajar nilai keagama dan sosial dan pemerintah memberikan bantuan PIP dan BOS bagi anak yang kurang mampu. 


\section{PENUTUP}

Berdasarkan hasil penelitian yang telah dipaparkan penulis pada bab sebelumnya, maka dapat disimpulkan bahwa: (1) Faktor anak putus sekolah di Desa Lambelu Kecamatan Pasikolaga yaitu di pengaruhi oleh dua faktor yakni faktor internal meliputi kurangnya minat atau kemauan anak dan kurangnya motivasi anak. Sedangkan faktor eksternal meliputi keterbatasan ekonomi orang tua, lingkungan pergaulan dan perkawinan usia muda. (2) Upaya mengatasi anak putus sekolah baik dari orang tua dan sekolah yaitu:

a. Orang tua harus memperhatikan dan sadar akan pentingnya pendidikananak mereka, hal tersebut dengan memberikaan dan dukungan dan motivasi baik dari segi moral maupun material, menjalin kedekatan dengan anak serta pendampingan belajar anak ketika berada di rumah.

b. Bentuk kepedulian dan perhatian sekolah dengan kolaborasi orang tua dengan mencari solusi apa yang menjadi permasalahan anak dan serta menjalin kedekatan dengan siswa-siswi agar mereka tidak merasa terabaikan dan diperhatikan selama di sekolah serta memberikan dukungan akan arti pentingnya pendidikan dan pemerintah memberikan bantuan PIP dan BOS serta bekerja sama dengan pemerintah desa untuk memberikan pemahaman kepada masyarakat, orang tua siswa tentang pentingnya pendidikan.

\section{DAFTAR PUSTAKA}

Asni. 2012. Pentingnya Pendidikan Formal. Skripsi Sarjana Unhalu Kendari.

Gunawan. 2004. Sosiologi Pendidikan: Suatu Analisis Sosiologi Tentang Pelbagai Problem Pendidikan. Jakarta: Rineka Cipta.

Imron. 2004. Manajemen Peserta Didik Berbasis Sekolah. Malang:Universitas Negeri Malang.

Mashun. 2010. Nilai-nilai Pendidikan Dongeng Pada Masyrakat Gu. Skripsi Sarjana Unhalu Kendari.

Purwanto. 2007. Psikologi Pendidikan. Bandung : PT Remaja Rosdakarya.

Salam, Burhanuddin. 2002. Pengantar Pedagogik. Jakarta: PT Rineka Cipta.

Sugiyono. 2009. Metode Penelitian Kuantitatif, Kualitatif dan R\&D. Bandung: Al-fabeta. 